Atıf/Citation: G. PEKCAN ERTOKUŞ, "Helikobakter pilori Tedavisinde Kullanılan Klaritromisin, Amoksisilin ve Lansorazolün İnsan İdrar Numunesinde Cok Değișkenli Kalibrasyon Yöntemleri ile Kantitatif Tayini”, Süleyman Demirel Üniversitesi Fen Edebiyat Fakültesi Fen Dergisi, 14, 89-96, 2019.

\title{
Helikobakter pilori Tedavisinde Kullanılan Klaritromisin, Amoksisilin ve Lansorazolün İnsan İdrar Numunesinde Çok Değişkenli Kalibrasyon Yöntemleri ile Kantitatif Tayini
}

\author{
Güzide PEKCAN ERTOKUŞ ${ }^{* 1}$ \\ ${ }^{I}$ Süleyman Demirel Üniversitesi, Fen-Edebiyat Fakültesi, Kimya Bölümü, 32260, Isparta, \\ Türkiye \\ *yazışılan yazar e-posta: guzideertokus@sdu.edu.tr
}

(Alınış / Received: 18.05.2018, Kabul / Accepted:28.03.2019, Yaylmlanma / Published: 31.05.2019)

Özet: Bu çalışmada kronik aktif gastrit ve peptik ülser hastalığında rolü olan Helikobakter pilorinin yok edilmesi için kullanılan klaritromisin, amoksisilin ve lansoprazol etken maddelerinin eş zamanlı spektrofotometrik olarak tayini yapılmıştır. Elde edilen verilere, çok değişkenli kalibrasyon yöntemleri - kemometrik metotlar başarı ile uygulanmıştır. Absorbanskonsantrasyon arasındaki ilişkiden yola çıkılarak sentetik karışım yardımıyla idrar numunesinde her bir aktif maddenin tayini gerçekleştirilmiş ve veriler MLR (Çoklu doğrusal regresyon), , PLS (Kısmi en küçük kareler yöntemi) ve PCR (Temel bileşen regresyonu) ile değerlendirilmiştir. MLR (Çoklu doğrusal regresyon), PLS (Kısmi en küçük kareler yöntemi) ve PCR (Temel bileşen regresyonu) kemometrik kalibrasyon metotlarındandır ve bu yöntemlerle elde edilen sonuçlar son derece hızlı ve en önemlisi güvenilirdir.

Anahtar kelimeler: Helikobakter pilori, MLR, PLS, PCR, UV.

\section{Quantitative Determination with Multivariate Calibration Methods Clarithromycin, Amoxicillin and Lansorazol in Used in Helicobacter pylori Treatment on Human Urine Sample}

\begin{abstract}
In this study, clarithromycin, amoxicillin, and lansoprazole agents for the treatment of Helicobacter pylori, which has a role in chronic active gastritis and peptic ulcer disease, has been determinated by the simultaneous spectrophotometric method. Multivariable calibration methods - chemometric methods have been successfully applied to the obtained data. Benefiting from the relationship between the absorbance and the concentration, with the aid of the synthetic mixture, in the urine sample was subjected to the determination of each active substance and the data were analyzed by MLR (Multi Linear Regression), PLS (Partial Least Squares Method) and PCR (Basic Component Regression). The MLR (Multiple Linear Regression), PLS (Partial Least Squares Method) and PCR (Principal Component Regression) are the methods of chemometric calibrations and the results obtained with these methods are extremely fast and most reliable.
\end{abstract}

Keywords: Helicobacter pylori, MLR, PLS, PCR, UV.

\section{Giriş}

Helikobakter pilori, gastrit ve diğer ülser türleriyle ilişkili bir gram-negatif bakteridir [1]. Helikobakter pilori, tedavi edilmediğinde gastrit kanserine neden olur [2,3], bu nedenle bu bakteri türünün yok edilmesi yaşam kalitesinin devam etmesi açısından önemlidir [4,5]. Helikobakter pilorinin tedavisinde, antisekretuvar ajan olarak proton inhibitörü ile iki farklı antibiyotik birlikte kullanılır [6,7]. Tedavide kullanılan ilaç türleri, klaritromisin 
[8], amoksisilin [9] ve lansoprazoldür [10]. Bu çalışmada Helikobakter pilori'nin tedavisinde kullanılan ilaç etken maddelerin yeni kurulan kemometrik kalibrasyon modeli üzerinden herhangi bir ön ayırma işlemi yapmadan, hızlı ve güvenilir bir şekilde kantitatif tayini yapılmıştır. Kemometrik kalibrasyon metotları, kompleks karışımlarındaki her bir bileşenin miktarını tayin etmek için kullanılan en iyi tekniklerdir, bunlardan bazıları temel bileşen regresyonu (PCR), kısmi en küçük kareler yöntemi (PLS) ve çoklu doğrusal regresyon (MLR) dir [11,12]. Absorbans ve konsantrasyon arasındaki bağıntıdan kurulan matrislerle, kemometrik metotlar oluşturulmuştur [13]. Elde edilen sonuçlara ANOVA testi uygulanarak hem sonuçlar, hem de yöntemin uygunluğu test edilmiştir [14,15,]. Çalışmamızda yer alan ilaç etken maddelerin literatürde yer alan farklı enstrümantal yöntemlerle analizleri mevcuttur. Bu çalışmalar, spektrofotometrik olarak [16] ve kromatografik [13] olarak yer almaktadır. Yine literatür incelendiğinde klaritromisin, amoksisilin ve lansoprazol etken maddelerinin insan idrar numunesinde kemometrik olarak farklı yöntemlerle tayinine rastlanmamıştır. Bu çalışmada elde edilen verilerin istatistik metotlarla değerlendirilmesi ile daha hassas ve güvenilir metotlar kazandırmak amaçlanmıştır.

\section{Materyal ve Metot}

Çalışmada kullanılan bütün kimyasal malzemeler (Sigma-Aldrich) analitik saflıktadır. Her bir ilaç etken maddesinin $100 \mathrm{ppm}$ olacak şekilde $0,1 \mathrm{M} \mathrm{HCl}$ in çözücü olarak kullanıldığı ortamda çözeltileri hazırlanmıştır. Deneyin diğer aşamalarında yer alan gerek tekli çözeltiler gerekse hazırlanan sententik karışımlar, her bir maddenin ayrı ayrı hazırlanmış 100 ppm'lik çözeltilerinden hazırlanır. Çalışmamızda kemometrik kalibrasyon yönteminde UV Spektrofotometrik absorbans değerleri kullanılmıştır. UV Spektrofotometri ölçümleri için UV 1700 Pharmaspec cihazı (Shimadzu, Kyoto, Japan) kullanılmıştır. Cihazdan okunan absorbans değerlerini kemometrik olarak değerlendirmek için elimizde lisansı bulunan Minitab 17 [17] ve XLSTAT [18] kullanılmıştır.

UV spektroskopisi yönteminde cihazın kalibrasyonu yapıldıktan sonra ilaç etken maddelerinin önce tek tek sonra 4,0-32,00 ppm derişim aralığında sentetik karışım çözeltileri ( Tablo 1.) saf standartlardan hazırlanarak spektrumları (Şekil 1.) alınmıştır. Sentetik karışımlar hazırlanırken, maddelerin birbiri yanında derişim değişimleri incelenmiştir. İlaç etken maddelerinden biri sabit tutulurken diğerinin değişimi incelenmiştir ve absorbans değerleri $0,1 \mathrm{~nm}$ aralıklarla okunmuştur. Okunan absorbans değerleri ve derişim arasındaki ilişkiden oluşturulan model üzerinden faydalanılarak, insan idrar numunesinin hazırlanması işlemine geçilmiştir. Bu aşamada, hiç ilaç tüketimi yapmayan kişiden alınan idrar örneği, 1/20 oranında seyreltilmiş ve bu çözeltiden $2 \mathrm{~mL}$ alınmıştır. Üzerine asetonitril ilavesi yapılarak son oluşan karışımdan alınan numune üzerine \% 10'luk asetonitril eklenmiştir. Bu numune üzerine ilaç kombinasyonu ilavesi ile absorpsiyon spektrum ölçümü adımına geçilmiş ve elde edilen verilerle her bir maddenin miktar tayini yapılmıştır. 
Tablo 1. Klaritromisin, amoksisilin ve lansoprazol ilaç etken maddelerini içeren derişim seti

\begin{tabular}{cccc}
\hline NO & Klaritromisin & $\begin{array}{c}\text { Derişim (ppm) } \\
\text { Amoksisilin }\end{array}$ & Lansoprazol \\
\hline 1 & 6 & 8 & 4 \\
2 & 6 & 16 & 12 \\
3 & 6 & 24 & 20 \\
4 & 6 & 32 & 28 \\
5 & 12 & 8 & 4 \\
6 & 12 & 16 & 12 \\
7 & 12 & 24 & 20 \\
8 & 12 & 32 & 28 \\
9 & 18 & 8 & 4 \\
10 & 18 & 16 & 12 \\
11 & 18 & 24 & 20 \\
12 & 18 & 32 & 28 \\
13 & 24 & 8 & 4 \\
14 & 24 & 16 & 12 \\
15 & 24 & 24 & 20 \\
16 & 24 & 32 & 28 \\
17 & 30 & 8 & 4 \\
18 & 30 & 16 & 12 \\
19 & 30 & 24 & 20 \\
20 & 30 & 32 & 28 \\
\hline
\end{tabular}

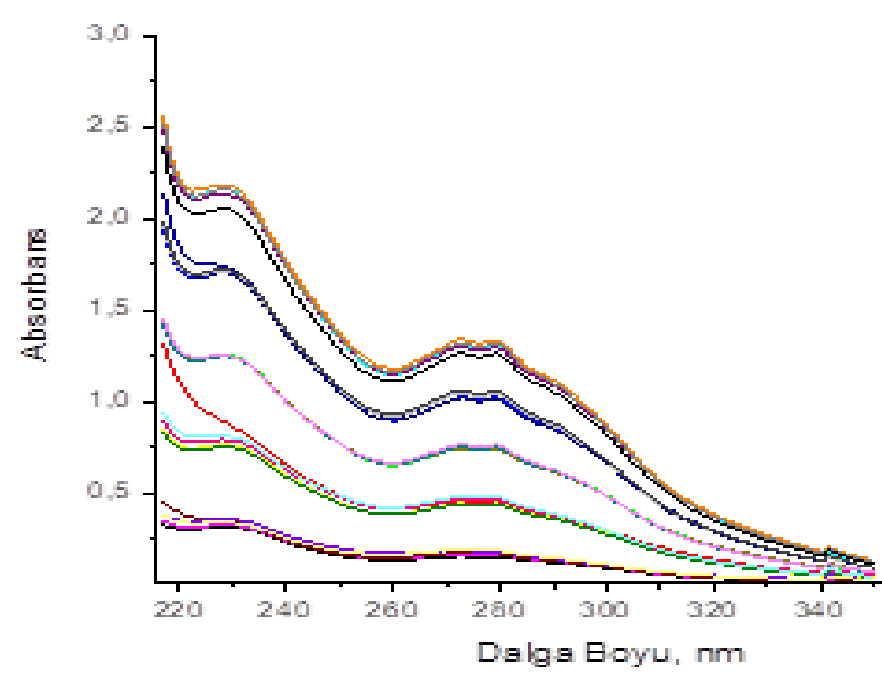

Şekil 1. Sentetik Karışımın Absorpsiyon Spektrumu

\section{Bulgular}

Her bir ilaç etken maddesinin insan idrar numunesindeki miktar tayinlerine geçmeden önce klaritromisin, amoksisilin ve lansoprazolün tekli halde spektrumları alınarak hangi dalga boyunda spektrum verdikleri yani maksimum dalga boyları (Tablo 2.) belirlenmiştir. Böylelikle hangi maddenin nerede maksimum dalga boyu gösterdiği belirlenmiştir.

Tablo 2. İlaç Etken Maddelerin Spektroskopik Özellikleri

\begin{tabular}{cccc}
\hline $\begin{array}{c}\text { Ilaç Etken } \\
\text { Maddesi }\end{array}$ & $\boldsymbol{\chi}_{\text {mak }}$ & Kalibrasyon Denklemi & $\begin{array}{c}\text { Korelasyon } \\
\text { Katsayısı }\end{array}$ \\
\hline Klaritromisin & $272,5 \mathrm{~nm}$ & $\mathrm{y}=0,0011 \mathrm{x}-0,0119$ & 0,9990 \\
Amoksisilin & $229,5 \mathrm{~nm}$ & $\mathrm{y}=0,0218 \mathrm{x}-0,0086$ & 0,9992 \\
Lansoprazol & $278,5 \mathrm{~nm}$ & $\mathrm{y}=0,033 \mathrm{x}-0,0514$ & 0,9997 \\
\hline
\end{tabular}

Çalışmada kullanılan 4,0-32,00 ppm aralığındaki derişim değerleri, tayin edilecek her bir bileșen için doğrusallığın olduğu bölgedir. Lambert-Beer [19] yasasına göre absorbans ve derişim arasındaki ilişski incelendiğinde iki değişken arasındaki doğrusallığı ifade eden 
korelasyon katsayısı [20] değerlerinin bire yakın olduğu gözlenmiştir. Bu aşamadan sonra kemometrik kalibrasyon aşamasına başlanmıştır. Kullanılan yöntemlerden

Çoklu doğrusal regresyon (MLR), regresyon eşitliğinin

$$
C_{i}=b_{0 i}+b_{1 i} A_{1}+b_{2 i} A_{2}+b_{3 i} A_{3}+\ldots \ldots .+b_{n i} A_{n}
$$

şeklinde bulunmasını içerir. Çoklu doğrusal regresyon için kalibrasyon örneklerinin sayısının tahmin edici sayısından daha fazla olması gerekmektedir [21].

Kemometrik kalibrasyonlardan en yaygın olanı kısmi en küşük kareler yöntemi (PLS) yöntemidir. PLS yönteminde kalibrasyonun kurulması için kullanılan PLS algoritmalarına göre, ortogonalize edilmiş PLS algoritması ve ortogonalize olmayan PLS algoritması kullanılır. Klasik metotlara göre elde edilen sonuçlar daha güvenilirdir [22].

Diğer bir kemometrik yöntem olan temel bileşen regresyon yöntemini ise derişim seti için ölçülen absorbans verilerinin dekomposizyonu ile birbirine dik (ortogonal) doğrular elde edilmesi esasına dayanır. Bu elde edilen doğrular kurulacak kalibrasyonun koordinat sistemidir ve hesaplamalar bu esasa dayandırılır [22].

Kemometrik hesaplamalara geçmeden ön basamak olarak temel bileşen analizi (PCA) işlemi yapılmıştır. Böylelikle elde bulunan verilerin miktarı hesaplanabilir boyuta getirilmiştir [23].

Tablo 1'deki kontrasyon setlerinden her bir kemometrik yöntem için hesaplanan geri kazanım ve bağıl standart sapma (BSS) değerleri tablo 3. tablo 4.ve tablo 5. de gösterilmiştir. İlave edilen derişimlere karşı bulunan derişimler hesaplanırken, çapraz validasyon işlemi uygulanarak, idrar numunesinde hatanın önüne geçilmiştir [24, 25].

Tablo 3. Sentetik Karışımın PLS Yöntemi İle Hesaplanan Sonuçları [26]

\begin{tabular}{|c|c|c|c|c|c|c|c|c|}
\hline \multicolumn{3}{|c|}{ İlave edilen derișim (ppm) } & \multicolumn{3}{|c|}{ Bulunan derișim (ppm) } & \multicolumn{3}{|c|}{ (\%) Geri Kazanım } \\
\hline Klaritromisin & Amoksisilin & Lansoprazol & Klaritromisin & Amoksisilin & Lansoprazol & Klaritromisin & Amoksisilin & Lansoprazol \\
\hline 6 & 8 & 4 & 5,99 & 8,11 & 3,88 & 98,83 & 101,38 & 97,00 \\
\hline 6 & 16 & 12 & 5,89 & 16,19 & 12,28 & 98,17 & 101,19 & 102,33 \\
\hline 6 & 24 & 20 & 5,91 & 23,56 & 19,86 & 98,50 & 98,17 & 99,30 \\
\hline 6 & 32 & 28 & 6,04 & 31,14 & 28,17 & 100,67 & 97,31 & 100,61 \\
\hline 12 & 8 & 4 & 11,78 & 8,31 & 4,04 & 98,17 & 103,88 & 101,00 \\
\hline 12 & 16 & 12 & 11,65 & 16,46 & 12,32 & 97,08 & 102,88 & 102,67 \\
\hline 12 & 24 & 20 & 12,27 & 24,14 & 19,63 & 102,25 & 100,58 & 98,15 \\
\hline 12 & 32 & 28 & 11,63 & 32,39 & 28,13 & 96,92 & 101,22 & 100,46 \\
\hline 18 & 8 & 4 & 18,46 & 7,64 & 3,85 & 102,56 & 95,50 & 96,25 \\
\hline 18 & 16 & 12 & 18,42 & 16,00 & 11,89 & 102,33 & 100,00 & 99,08 \\
\hline 18 & 24 & 20 & 18,17 & 24,22 & 20,07 & 100,94 & 100,92 & 100,35 \\
\hline 18 & 32 & 28 & 18,32 & 31,83 & 27,81 & 101,78 & 99,47 & 99,32 \\
\hline 24 & 8 & 4 & 24,02 & 8,18 & 4,09 & 100,08 & 102,25 & 102,25 \\
\hline 24 & 16 & 12 & 24,02 & 16,2 & 12,02 & 100,08 & 101,25 & 100,17 \\
\hline 24 & 24 & 20 & 24,74 & 24,27 & 20,08 & 103,08 & 101,13 & 100,40 \\
\hline 24 & 32 & 28 & 24,75 & 32,21 & 28,99 & 103,13 & 100,66 & 103,54 \\
\hline 30 & 8 & 4 & 30,33 & 7,93 & 3,88 & 101,10 & 99,13 & 97,00 \\
\hline 30 & 16 & 12 & 30,43 & 16,82 & 12,07 & 101,43 & 105,13 & 100,58 \\
\hline 30 & 24 & 20 & 29,98 & 24,12 & 20,15 & 99,93 & 100,50 & 100,75 \\
\hline 30 & 32 & 28 & 29,82 & 32,11 & 28,03 & 99,40 & 100,34 & 100,11 \\
\hline & & & & & & ort: 100,32 & ort: 100,64 & ort: 100,06 \\
\hline & & & & & & BSS: 1,92 & BSS:2,14 & BSS:1,92 \\
\hline
\end{tabular}


Tablo 4. Sentetik Karışımın PCR Yöntemi İle Hesaplanan Sonuçları [26]

\begin{tabular}{|c|c|c|c|c|c|c|c|c|}
\hline \multicolumn{3}{|c|}{ İlave edilen derişim (ppm) } & \multicolumn{3}{|c|}{ Bulunan derişim (ppm) } & \multicolumn{3}{|c|}{ (\%) Geri Kazanım } \\
\hline Klaritromisin & Amoksisilin & Lansoprazol & Klaritromisin & Amoksisilin & Lansoprazole & Klaritromisin & Amoksisilin & Lansoprazol \\
\hline 6 & 8 & 4 & 5,86 & 8,01 & 4,01 & 97,67 & 100,12 & 100,25 \\
\hline 6 & 16 & 12 & 5,78 & 15,95 & 11,96 & 96,33 & 99,69 & 99,67 \\
\hline 6 & 24 & 20 & 5,81 & 24,01 & 20,01 & 96,83 & 100,04 & 100,05 \\
\hline 6 & 32 & 28 & 6,04 & 31,86 & 27,89 & 100,67 & 99,56 & 99,61 \\
\hline 12 & 8 & 4 & 11,77 & 8,02 & 3,96 & 98,08 & 100,25 & 99,00 \\
\hline 12 & 16 & 12 & 11,6 & 15,96 & 11,96 & 96,67 & 99,75 & 99,67 \\
\hline 12 & 24 & 20 & 11,75 & 23,95 & 19,98 & 97,92 & 99,79 & 99,90 \\
\hline 12 & 32 & 28 & 11,63 & 32,01 & 27,96 & 96,92 & 100,03 & 99,86 \\
\hline 18 & 8 & 4 & 17,78 & 7,96 & 4,01 & 98,78 & 99,50 & 100,25 \\
\hline 18 & 16 & 12 & 17,85 & 15,95 & 11,96 & 99,17 & 99,69 & 99,67 \\
\hline 18 & 24 & 20 & 17,76 & 24,01 & 19,95 & 98,67 & 100,04 & 99,75 \\
\hline 18 & 32 & 28 & 18,23 & 31,98 & 27,96 & 101,28 & 99,94 & 99,86 \\
\hline 24 & 8 & 4 & 24,01 & 7,85 & 3,95 & 100,04 & 98,13 & 98,75 \\
\hline 24 & 16 & 12 & 23,96 & 15,96 & 11,95 & 99,83 & 99,75 & 99,58 \\
\hline 24 & 24 & 20 & 23,86 & 24,01 & 19,96 & 99,42 & 100,04 & 99,80 \\
\hline 24 & 32 & 28 & 23,95 & 32,21 & 27,96 & 99,79 & 100,66 & 99,86 \\
\hline 30 & 8 & 4 & 29,69 & 7,94 & 3,96 & 98,97 & 99,25 & 99,00 \\
\hline 30 & 16 & 12 & 29,75 & 15,96 & 11,96 & 99,17 & 99,75 & 99,67 \\
\hline 30 & 24 & 20 & 29,85 & 23,95 & 19,95 & 99,50 & 99,79 & 99,75 \\
\hline 30 & 32 & 28 & 30,01 & 31,95 & 27,89 & 100,03 & 99,84 & 99,61 \\
\hline & & & & & & ort: 98,79 & ort: 99,78 & ort: 99,68 \\
\hline & & & & & & BSS: 1,40 & BSS:0,49 & BSS:0,38 \\
\hline
\end{tabular}

Sentetik Karışımların hazırlanmasında [26] çalışmadaki bazı veriler kullanılmıştır.

Sonraki hesaplamalar baştan tekrarlanarak ve yöntem eklenerek yapılmıştır.

Tablo 5. Sentetik Karışımın MLR Yöntemi İle Hesaplanan Sonuçları

\begin{tabular}{|c|c|c|c|c|c|c|c|c|}
\hline \multicolumn{3}{|c|}{ İlave edilen derişim (ppm) } & \multicolumn{3}{|c|}{ Bulunan derişim (ppm) } & \multicolumn{3}{|c|}{ (\%) Geri Kazanım } \\
\hline Klaritromisin & Amoksisilin & Lansoprazol & Klaritromisin & Amoksisilin & Lansoprazole & Klaritromisin & Amoksisilin & Lansoprazol \\
\hline 6 & 8 & 4 & 5,98 & 7,96 & 3,96 & 99,67 & 99,50 & 99 \\
\hline 6 & 16 & 12 & 5,96 & 15,94 & 11,94 & 99,33 & 99,63 & 99,5 \\
\hline 6 & 24 & 20 & 5,89 & 23,97 & 19,95 & 98,17 & 99,88 & 99,75 \\
\hline 6 & 32 & 28 & 5,94 & 31,99 & 27,99 & 99,00 & 99,97 & 99,96 \\
\hline 12 & 8 & 4 & 11,92 & 7,89 & 3,89 & 99,33 & 98,63 & 97,25 \\
\hline 12 & 16 & 12 & 11,95 & 15,97 & 11,97 & 99,58 & 99,82 & 99,75 \\
\hline 12 & 24 & 20 & 11,96 & 23,92 & 19,94 & 99,67 & 99,67 & 99,7 \\
\hline 12 & 32 & 28 & 11,97 & 31,97 & 27,96 & 99,75 & 99,91 & 99,86 \\
\hline 18 & 8 & 4 & 17,98 & 7,95 & 3,95 & 99,89 & 99,38 & 98,75 \\
\hline 18 & 16 & 12 & 17,99 & 15,98 & 11,98 & 99,94 & 99,88 & 99,83 \\
\hline 18 & 24 & 20 & 17,95 & 23,92 & 19,97 & 99,72 & 99,67 & 99,85 \\
\hline 18 & 32 & 28 & 17,95 & 31,93 & 27,96 & 99,72 & 99,78 & 99,86 \\
\hline 24 & 8 & 4 & 23,94 & 7,95 & 3,97 & 99,75 & 99,38 & 99,25 \\
\hline 24 & 16 & 12 & 23,99 & 15,99 & 11,95 & 99,96 & 99,94 & 99,58 \\
\hline 24 & 24 & 20 & 23,96 & 23,96 & 19,99 & 99,83 & 99,83 & 99,95 \\
\hline 24 & 32 & 28 & 23,89 & 31,99 & 27,93 & 99,54 & 99,97 & 99,75 \\
\hline 30 & 8 & 4 & 29,94 & 7,92 & 3,94 & 99,80 & 99,00 & 98,5 \\
\hline 30 & 16 & 12 & 29,96 & 15,96 & 11,96 & 99,87 & 99,75 & 99,67 \\
\hline 30 & 24 & 20 & 29,87 & 23,94 & 19,97 & 99,57 & 99,75 & 99,85 \\
\hline 30 & 32 & 28 & 30 & 31,94 & 27,94 & 100,00 & 99,81 & 99,79 \\
\hline & & & & & & ort: 99,60 & ort:99,66 & ort: 99,47 \\
\hline & & & & & & BSS:0,42 & BSS:0,34 & BSS:0,66 \\
\hline
\end{tabular}

Çok değişkenli kalibrasyon yöntemleri ile sonuçlar hesaplandıktan sonra uygulanan yöntemlerin uygunluğunu kıyaslamak için varyans analizi (ANOVA testi) yapılmıştır. ANOVA [27] testinde grup içi ve gruplar arası standart sapma değerlerinden hesaplanan $\mathrm{F}$ değerleri ile teorikte olması gereken $\mathrm{F}$ değerleri kıyaslanmış ve pearson korelasyon katsayısının 0,05 'e ya eşit ya da büyük değerde elde edilişi incelenmiştir. Tablo 6'daki değerler incelendiğinde hesaplanan değerlerin, kritik değerden küçük olduğu görülmektedir. Bu sonuçlar bu çalışma için kullanılan yöntemlerin uygun olduğunu göstermektedir. 
Tablo 6. Varyans Analizi (ANOVA) Sonuçları

\begin{tabular}{ccccc}
\hline Yöntem & \multicolumn{3}{c}{ F hesaplanan değer } & F kritik değer \\
\hline PLS & Klaritromisin & Amoksisilin & Lansoprazol & 4,10 \\
& 0,0022 & 0,0010 & 0,00045 & 4,10 \\
PCR & Klaritromisin & Amoksisilin & Lansoprazol & \\
& 0,0031 & 0,00007 & 0,0002 & 4,10 \\
MLR & Klaritromisin & Amoksisilin & Lansoprazol & \\
& 0,0003 & 0,0003 & 0,0002 & \\
\hline
\end{tabular}

Tahmin değerlerin validasyon ifadesinde performansının geçerliliği çapraz geçerlilik yöntemi kullanılarak tahminsel kalıntısal hata (karelerin tahmin (tayin) hatalarının toplamı: PRESS) (Denklem 1) hesaplanmıştır. Bu değerin sıfıra yakın olması kullanılan modelin tahmin gücünün iyi olduğunu göstermektedir [29]. Validasyondaki diğer parametreler kalibrasyonun standart hatasi: SEC (Denklem 2) ve tahminin kareler ortalamasının karekökü: RMSEC [29] (Denklem 3) olarak ifade edilmiştir.

$$
\begin{aligned}
& \text { PRESS }=\sum_{i=1}^{n}\left(C_{i}^{\text {ilaveEdila }}-C_{i}^{\text {Bulunan }}\right)^{2} \\
& S E C=\sqrt{\frac{\sum_{i=1}^{n}\left(C_{i}^{\text {ilaveEdila }}-C_{i}^{\text {Bulunan }}\right)^{2}}{n-1}} \\
& R M S E C=\sqrt{P R E S S / n} \\
& C_{i}^{\text {ilaveEdilan }}: \text { Ortama ilave edilen gerçek derişism } \\
& C_{i}^{\text {Bulunan }}: \text { Hesaplanan tahmini derişim } \\
& \mathrm{n} \quad: \text { Numune sayısı }
\end{aligned}
$$

Tablo 7. Kemometrik Yöntemlerin Hesaplanan Validasyon Parametreleri

\begin{tabular}{lllll}
\hline Parameter & Metot & Klaritromisin & Amoksisilin & Lansoprazol \\
\hline RMSEC & PLS & 0,076 & 0,08 & 0,062 \\
& PCR & 0,055 & 0,03 & 0,055 \\
\multirow{2}{*}{ PRESS } & MLR & 0,014 & 0,012 & 0,010 \\
& PLS & 0,118 & 0,128 & 0,076 \\
& PCR & 0,045 & 0,0055 & 0,003 \\
\multirow{2}{*}{ SEC } & MLR & 0,0037 & 0,0030 & 0,002 \\
& PLS & 0,089 & 0,094 & 0,061 \\
& PCR & 0,061 & 0,018 & 0,015 \\
& MLR & 0,017 & 0,016 & 0,015 \\
\hline
\end{tabular}

Yöntemin uygunluğu ve validasyon parametreleri incelendikten sonra insan idrar numunesinde klaritromisin, amoksisilin ve lansoprazolün analizi yapılmıştır. UV spektroskopisinde ölçümler alınarak, veriler çok değişkenli kemometrik kalibrasyon yöntemleri ile incelenmiştir (Tablo 8.). 
Tablo 8. İdrar Numunesindeki Sonuçlar

\begin{tabular}{|c|c|c|c|c|c|c|c|c|}
\hline \multicolumn{3}{|c|}{ İlave edilen derişim (ppm) - PLS } & \multicolumn{3}{|c|}{ Bulunan derişim (ppm) - PLS } & \multicolumn{3}{|c|}{ (\%) Geri Kazanım - PLS } \\
\hline 12 & 12 & 12 & 11,95 & 11,88 & 11,95 & 99,58 & 99,00 & 99,58 \\
\hline 20 & 20 & 20 & 19,89 & 19,87 & 20,01 & 99,45 & 99,35 & 100,05 \\
\hline \multirow{2}{*}{28} & & & & & & ort $: 99,37$ & ort $: 99,43$ & ort: 99,48 \\
\hline & & & & & & BSS:0,25 & BSS:0,36 & BSS:0,68 \\
\hline \multicolumn{3}{|c|}{ İlave edilen derisim (ppm) - PCR } & \multicolumn{3}{|c|}{ Bulunan derișim (ppm) - PCR } & \multicolumn{3}{|c|}{ (\%) Geri Kazanım - PCR } \\
\hline 12 & 12 & 12 & 11,89 & 11,96 & 11,98 & 99,08 & 99,67 & 99,83 \\
\hline 20 & 20 & 20 & 18,98 & 19,95 & 19,99 & 94,90 & 99,75 & 99,95 \\
\hline \multirow[t]{3}{*}{28} & 28 & 28 & 27,88 & 27,94 & 27,96 & 99,57 & 99,79 & 99,86 \\
\hline & & & & & & ort : 98,08 & ort :99,62 & ort:99,27 \\
\hline & & & & & & BSS:2,14 & BSS: 0,25 & BSS: 1,19 \\
\hline \multicolumn{3}{|c|}{ İlave edilen derişim (ppm) - MLR } & \multicolumn{3}{|c|}{ Bulunan derișim (ppm) - MLR } & \multicolumn{3}{|c|}{ (\%) Geri Kazanım - MLR } \\
\hline \multirow[t]{3}{*}{28} & 28 & 28 & 27,96 & 28 & 27,94 & 99,86 & 100 & 99,79 \\
\hline & & & & & & ort :99,66 & ort $: 98,89$ & ort: 99,67 \\
\hline & & & & & & BSS:0,16 & BSS: 1,34 & BSS: 0,30 \\
\hline
\end{tabular}

\section{Sonuç ve Yorum}

Bu çalışma esnasında UV Spektofotometri yöntemi ile elde edilen veriler çok değişkenli kemometrik yöntemler ile değerlendirilmiştir. Kemometrik metotlarla hesaplanan tahmini veriler ve idrar numunesindeki değerler, analitik olarak incelenmiştir.

Herbir maddenin tekli halde spektrumları alınıp spektroskopik özellikleri belirlendikten sonra sentetik karışımlardaki miktar tayinleri yapılarak tahmini yani bulunan değerler hesaplanmıştır. Bu verilerden yola çıkılarak \% geri kazanım ve bağıl standart sapma değerleri hesaplanmıştır. Bu sonuçlara bakıldığında geri kazanım değerlerini yüze yakın standart sapma değerlerinin de küçük değerler olduğu görülmüştür. Bir sonraki aşamada ANOVA testi ile hesaplanan verilerin uyumluluğu ve kullanılan yöntemlerin uygunluğu test edilmiştir. Sonuçlara bakıldığında, hesaplanan F değerlerinin teorik değerlerden küçük olduğu gözlenerek yöntemlerin ve sonuçların uygunluğuna karar verilmiştir. ANOVA testinden sonra sonuçlar valide edilmiştir. PRESS, SEC ve RMSEC parametreleri her bir yöntem için hesaplanmış ve değerler sıfıra yakın olarak elde edilmiştir. Bütün kontroller yapıldıktan sonra idrar numunesindeki sonuçlar hesaplanmıştır. \% Geri kazanım ve BSS değerleri hesaplanarak analitik olarak sonuçların güvenilir ve doğru olduğuna karar verilmiştir. Böylelikle kullanılan kemometrik metotların idrar numunelerinin analizlerinde yüksek duyarlılıkta olup sonuçların tekrarlanabilir olduğu gözlemlenmiştir.

\section{Kaynakça}

[1] A. Sameh, N.N. Atia, "Simultaneous determination of triple therapy for Helicobacter pylori in human plasma by reversed phase chromatography with online wavelength switching", Spectrochim Acta A: Mol Biomol Spectrosc, 136, 1380- 1387, 2015.

[2] D.Y. Graham, "Treatment of peptic ulcers caused by Helicobacter pylori”, N. Engl. J. Med., vol. 328, pp. 349-350. 1993.

[3] S.V. Zanten, P. Sherman, "Indications for the treatment of Helicobacter pylori: a systematic overview, Can.Med. Ass J., vol. 150, pp. 177-185, 1994.

[4] P. Lulie, D.F. Gary, P. Daniel, Y.C. Vandersteen, H. Joseph, D.E.E. Vogelman, O. Norman, K.S. Richard, "Helicobacter pylori infection and the risk of gastric carcinoma", N. Engl. J. Med., vol. 325, pp. 1127-1131, 1991.

[5] F.C. Ramirez, G. Lew, P.D. Klein, R.M. Genta, D.Y. Graham, "Search for improved anti- Helicobacter pyloritherapies", Am. J. Gastroenterol, vol. 87, pp. 1275-1279, 1992. 
[6] N. Vakil, "The montreal definition and classification of gastroesophageal reflux disease: a global evidence-based consensus", Am. J. Gastroenterol, 8, 1900-1920, 2006.

[7] I. Satoshi, M. Fukuto, S. Kazufumi, M. Shinichi, T. Masahiko, K. Kiyomi, O. Kozue, H. Mayayoshi, K. Yoshiyuki, O. Hitoyoshi, "In vivo bactericidal activities oj Japanase rice-fluid against $H$. pylori in a Mongolian gerbil model, Int. J. Med. Sci., 4, 203-208, 2007.

[8] Uygun, A. Kadayıfçı, Z. Yeşilova, M.C. Savaş, Y. Ateş, Y. Karslıŏlu, M. Ciğerim, S. Bağcı, K. Dağalp, " Recent success of pantoprazole-or lansoprazole- based clarithromycin plus amoxicillin treatment in the eradication of Helicobacter pylori ", Turk J. Gastroenterol, 4, 219-224, 2004.

[9] M. Horoz, C. Bölükbaş, F.F. Bölükbaş, A. Uzunköy, A. Soylu, "Klaritromisin-AmoksisilinLansoprazol Kombinasyonunda Optimal Tedavi Süresi, HrÜ. Tıp Fak. Der., 1, 12-19, 2004.

[10] A Uygun, A. Tüzün, Z. Yeşilova, M. Aslan, Y. Ateş, Z. Polat, A. Erdil, S. Bağc1, Ö. Günhan, M. Gülşen, K. Dağalp, "Helicobacter pylori eradikasyon tedavisinde 7 ve 14 günlük lansoprazol, amoksisiln, klaritromisin protokolünün karşılaştırılması”, Akademik Gastroentreroji Dergisi, 4-3, 172175, 2005.

[11] E. Dinç, D. Baleanu, “ Spectrophotometric quantitative determination of cilazapril and hydrochlorothiazide in tablets by chemometric methods" JPBA, 30, 715-723, 2002.

[12] E. Dinç,A. Özdemir, D. Baleanu, "Comparative study of the continuous wavelent transform, derivative and partial least squares methods applied to the overlapping spectra for the simultaneous quantitative resolution of ascorbic acid and asetilsalicylic acid in effervescent tablets, JPBA, 37, 715-723, 2005.

[13] A.H. Aktaş, A.M. Sarıdağ, "Liquid chromatografic-chemometric tecnhniques for the simultaneous HPLC determination of lansoprazole, amoksisilin and clarithromisin in commercial preparation", $J$. Chromatogr. Science, pp. 1-7, 2017.

[14] A. Kaba, A.H. Aktaş, "Çeşitli Ligandları Kullanarak $\mathrm{Fe}^{3+}, \mathrm{Al}^{3+}$ ve $\mathrm{Cu}^{2+}$ nin $\mathrm{Bir}$ Arada Spektrofotometrik Tayinleri İçin Yöntem Geliştirilmesi ve Elde Edilen Verilerin En Küçük Kareler Kalibrasyon Yöntemi (PLS) ve Temel Bileşen Regresyon (PCR) Yöntemi ile Değerlendirilmesi”, SAUFBE, 18, 1, 71-79, 2014.

[15] A.H. Aktaş, B. Mutlutürk, "Demir ve Alüminyumun Doğal Sularda UV Spektrofotometrik Tayini için Yöntem Geliştirilmesi ve Elde Edilen Verilerin Kemometrik Kalibrasyon Yöntemleriyle Değerlendirilmesi”, Süleyman Demirel Üniversitesi Fen Bilimleri Enstitüsü Dergisi, 18, 3, 52-59, 2014.

[16] A.H. Aktaş, H.H. Toprak, "Spectrometric determination of lansoprazole and domperidone in tablets by multivariate calibration approach", JOCPR, 9, 3, 103-108.

[17] Minitab 17 Statistical Programme: http://www.inovadanismanlik.com.tr (18.05.2018)

[18] XLSTAT Pragramme: https://www.xlstat.com/en/ (18.05.2018)

[19] D. Sharma, R. Singh, R. Garg, "Development and validation of stability indicating UV spectrophotometric method for the estimation of benzydamine hydrochloride in bulk and in pharmaceutical dosage form: a novel analytical technique for conducting in-vitro quality control tests", International Journal of Pharmaceutical Sciences and Research, vol. 9(2), pp. 678-686, 2017.

[20] J. Miao, B. Forget, K. Smith, "Predicting Correlation Coefficients for Monte Carlo Eigenvalue Simulations With Multitype Branching Process", Ann. Nucl. Energy, 112, 307-321, 2018.

[21] M. Bahçecitapar, S. Aktaş, "Çoklu doğrusal bağlantı durumunda doğrusal karma modelin kullanımı ve bir uygulama”, SAUJS, 21, 6, 1349-1359, 2017.

[22] E. Dinç, "Kemometrik İşlem ve Yöntemlerin Analitik Kimyadaki Tipik Uygulamaları”, Uygulamalı Kemometri Yaz Okulu Notlarl, pp. 13-17, 2009.

[23] P. Saganowska, M. Wesolowski, "Principal Component and Cluster Analyses as Supporting Tools for Co-Crystals Detection", J. Therm. Anal. Calorim., 130, 45-55, 2017.

[24] A. Porfire, D. Muntean, M. Achim, L. Vlase, I. Tomuta, "Simultaneous Quantification of Simvastatin and Excipients in Liposomes Using Near Spectroscopy and Chemometry”, JPBA, 107, 40-49, 2015.

[25] I.Tarhan, A.A.I.H Kara, "Quantitative Determination of Free Fatty Acids in Extra Virgin Olive Oils by Multivariate Methods and Fourier Transform Infrared Spectroscopy Considering Different Absorption Modes", Int J. Food Prop., 1-8, 2017.

[26] G. Pekcan Ertokuş, K. Bağrıaçık, "Simultaneous determination of drugs used for chronic active gastritis disease by chemometric methods", IJLTET, 8, 4, 173-178, 2017.

[27] V. Bajpai, S. Kumar, A. Singh, J. Singh, M.P.S. Negi, S.K. Bag, N. Kumar, R. Konwar, B. Kumar, "Chemometric based identification and validation of specific chemical markers for goegraphical, seasonal and gender variations in tinospora cordifolia stem using HPLC-ESI-QTOF-MS Analysis”, Phytochem. Anal., 28(4), 277-288, 2017.

[28] A. Uyanık, “ Analitik Kimyacılar İçin İstatistik ve Kemometri”, Pegem Akademi Yayıncılık, 6. Baskı, pp. 254-259, 2012.

[29] A.V. Bilgili, M.A.Çullu, S. Aydemir, "Tuzdan etkilenmiş toprakların yakın kızılötesi yansıma spektroradyometre ve elektromanyetik indüksiyon tekniği yardımıyla karakterize edilebilme potansiyelinin araştırılması", Harran Tarım ve Gıda Bilimleri Dergisi, 18(1), 32-45, 2014. 